\title{
Isoxazole Derivatives as Regulators of Immune Functions
}

\author{
Michał Zimecki ${ }^{1}$, Urszula Bąchor ${ }^{2}$ and Marcin Mączyński ${ }^{2, * \mathbb{D}}$ \\ 1 Laboratory of Immunobiology, Institute of Immunology and Experimental Therapy, Polish Academy of \\ Sciences, Weigla 12, 53-114 Wroclaw, Poland; zimecki@iitd.pan.wroc.pl \\ 2 Department of Organic Chemistry, Faculty of Pharmacy, Wroclaw Medical University, Borowska 211a, \\ 50-556 Wroclaw, Poland; urszula.bachor@umed.wroc.pl \\ * Correspondence: marcin.maczynski@umed.wroc.pl; Tel.: +48-717840344
}

Received: 4 October 2018; Accepted: 20 October 2018; Published: 22 October 2018

check for updates

\begin{abstract}
In this review, we present reports on the immunoregulatory properties of isoxazole derivatives classified into several categories, such as immunosuppressive, anti-inflammatory, immunoregulatory, and immunostimulatory compounds. The compounds were tested in various models using resident cells from rodents and humans, cell lines, and experimental animal disease models corresponding to human clinical situations. Beneficial features of the described isoxazole derivatives include low toxicity and good bioactivity at low doses. In a majority of studies, the activities of investigated compounds were comparable or even higher than registered reference drugs. Whenever possible, a plausible mechanism of action of the investigated compounds and their potential therapeutic utility were proposed. Among the described compounds, particular attention was paid to the class of immune stimulators with a potential application in chemotherapy patients.
\end{abstract}

Keywords: isoxazoles; anti-inflammatory; immune suppression; immune stimulation

\section{Introduction}

Compounds containing the isoxazole ring [1] serve as an important source of valuable drugs that are designed to treat infections and diseases of different etiologies. Syntheses, classification, mechanisms of action, and the therapeutic application of registered isoxazole derivatives, as well as these under preclinical investigations, were recently in detail described in several reviews [2-5]. Therefore, we wished to focus in this short review only on data regarding the immunoregulatory properties of compounds containing the isoxazole ring. Although a majority of isoxazole derivatives under interest display immunosuppressive activities, including anti-inflammatory ones, less is known about immunostimulatory compounds of potential therapeutic utility. Such a group of compounds, besides immunosuppressive molecules, was also synthesized, and their potential therapeutic usefulness evaluated by our research team. In this review, the results regarding immunoregulatory actions of selected isoxazole derivatives in various immunological settings in vitro and in vivo human and rodent models are described (Table 1). In some investigations, the description of the immunoregulatory properties is accompanied with the suggested mechanism of action, and potential therapeutic applications are proposed. 
Table 1. Isoxazole derivatives with potential application in therapy.

\begin{tabular}{|c|c|c|c|c|}
\hline Compound & Structure & Activity & Molecular/Cellular Mechanism of Action & Reference Number \\
\hline \multicolumn{5}{|c|}{ Immunosuppressive actions } \\
\hline $\begin{array}{l}\text { HWA-486/Leflunomide 5-methyl- } N \text {-[4- } \\
\text { (trifluoromethyl)phenyl]-1,2-oxazole-4-carboxamide }\end{array}$ & & $\begin{array}{l}\text { Immunosuppressive and anti-inflammatory } \\
\text { regulation of autoimmune lymphocytes }\end{array}$ & $\begin{array}{l}\text { COX-2 inhibitor, non-cytotoxic inhibitor of } \\
\text { dihydroorotate dehydrogenase }\end{array}$ & [6] \\
\hline Parecoxib & & Anti-inflammatory registered drug & COX-2 inhibitor & [7] \\
\hline $\begin{array}{l}\text { 8g/5-(4-amino-5-benzoyl-1,2-oxazol-3-yl)- } N \text { - } \\
\text { [(pyridin-4-yl)methyl]-1,3,4-oxadiazole- } \\
\text { 2-carboxamide }\end{array}$ & & $\begin{array}{l}\text { Inhibits the proliferative response of mouse } \\
\text { splenocytes to concanavalin } \mathrm{A} \\
\text { suppresses the humoral immune response }\end{array}$ & N.D. & [8] \\
\hline $\begin{array}{l}\text { 10f/5-(5-amino-7-phenyl[1,2]oxazolo[4,5-d] } \\
\text { pyrimidin-3-yl)- } N \text {-[(pyridin-3 } \\
\text {-yl)methyl]-1,3,4-oxadiazole-2-carboxamide }\end{array}$ & & $\begin{array}{l}\text { Stimulates mitogen-induced proliferation of } \\
\text { mouse splenocytes, suppresses DTH }\end{array}$ & N.D. & {$[8]$} \\
\hline $\begin{array}{l}\text { 4d/5-(2-hydroxyethyl)piperazinomethinimino-3 } \\
\text {-methyl-4-isoxazolecarboxylic acid 4- } \\
\text { (4-ethoxyphenyl)-amide }\end{array}$ & & $\begin{array}{l}\text { Inhibits the DTH and humoral immune } \\
\text { response to SRBC in vitro and in vivo }\end{array}$ & N.D. & [9] \\
\hline $\begin{array}{c}\text { RM-33/3,5,7-trimethyl-5,6,7,8-tetrahydro- } \\
4 H \text {-[1,2]oxazolo[5,4- } \\
e][1,2,4] \text { triazepin-4-one }\end{array}$ & & $\begin{array}{l}\text { Inhibits LPS-induced TNF- } \alpha \text { and IL- } 6 \text { activity } \\
\text { inhibits antibody production }\end{array}$ & $\begin{array}{l}\text { * Stimulation of caspase } 9 \text { expression in } \\
\text { thymocytes and splenocytes and Fas in } \\
\text { bone marrow cells and splenocytes, } \\
\text { inhibition of ERK } 1 \text { and p38g in bone } \\
\text { marrow cells }\end{array}$ & [10] \\
\hline
\end{tabular}


Table 1. Cont.

\begin{tabular}{|c|c|c|c|c|}
\hline Compound & Structure & Activity & Molecular/Cellular Mechanism of Action & Reference Number \\
\hline $\begin{array}{l}\text { 1020/5-\{[(4-hydroxyphenyl)methylidene]amino\}- } \\
\text { 3-methyl[1,2]oxazolo[5,4- } \\
\text { emphd]pyrimidin-4(5H)-one }\end{array}$ & & $\begin{array}{l}\text { Displays strong immunosuppressive action, } \\
\text { inhibits polyclonal antibody production }\end{array}$ & N.D. & [11] \\
\hline $\begin{array}{l}\text { 1025/5-(cyclohexylideneamino)-3-methyl[1,2]oxazolo } \\
\text { [5,4-d]pyrimidin- } 4(5 \mathrm{H}) \text {-one }\end{array}$ & & $\begin{array}{l}\text { Shows immunosuppressive property, lowers } \\
\text { polyclonal antibody production }\end{array}$ & N.D. & [11] \\
\hline $\begin{array}{l}\text { M5/2-[(5-amino-3-methylisoxazol-4-yl)carbonyl]- } \\
\text { N-(4-chlorophenyl)hydrazinecarboxamide }\end{array}$ & & Inhibits antibody production in mice & N.D. & [12] \\
\hline $\begin{array}{l}\text { RM56/5-(5-amino-3-methyl-1,2-oxazol-4-yl)-1,3,4- } \\
\text { oxadiazol-2-amine }\end{array}$ & & $\begin{array}{c}\text { Inhibits the humoral immune response, the } \\
\text { carrageenan reaction and proliferation of } \\
\text { lymphocytes }\end{array}$ & N.D. & [13] \\
\hline $\begin{array}{l}\text { MO5/5-amino-3-methyl- } N \text {-[(4-methylphenyl) } \\
\text { methyl]-1,2-oxazole-4-carboxamide }\end{array}$ & & $\begin{array}{l}\text { Inhibits the humoral immune response } \\
\text { in vitro }\end{array}$ & Inhibitor of TNF $\alpha$ production & [14] \\
\hline 5-amino-3-methyl-1,2-oxazole-4-carbohydrazide & & $\begin{array}{l}\text { Modulates the content of } \mathrm{T} \text { cell subsets and } \mathrm{B} \\
\text { cells in lymphoid organs, and elevates the } \\
\text { humoral immune response in mice }\end{array}$ & $\begin{array}{l}\text { Upregulation of fractalkine (CX3CL1) and } \\
\text { IL-17F, and downregulation of IL-10 and } \\
\text { TLR4 }\end{array}$ & [15] \\
\hline $\begin{array}{l}\text { MM3/5-amino- } N^{\prime} \text {-[2-(2,4-dihydroxyphenyl) } \\
\text { ethylidene]- } N, 3 \text {-dimethyl-1,2-oxazole-4 } \\
\text {-carbohydrazide }\end{array}$ & & $\begin{array}{l}\text { Inhibits the mitogen-induced proliferation of } \\
\text { PBMC and LPS-induced TNF } \alpha \text { production } \\
\text { in human blood cell culture }\end{array}$ & $\begin{array}{l}\text { Strong increases in the expression of } \\
\text { caspases, Fas, and NF-kB1 }\end{array}$ & [16] \\
\hline
\end{tabular}


Table 1. Cont.

\begin{tabular}{|c|c|c|c|c|}
\hline Compound & Structure & Activity & Molecular/Cellular Mechanism of Action & Reference Number \\
\hline \multicolumn{5}{|c|}{ Immune regulators } \\
\hline $\begin{array}{l}\text { HWA-486/Leflunomide 5-methyl- } \mathrm{N} \text {-[ } \\
\text { 4-(trifluoromethyl)phenyl]-1,2-oxazole-4-carboxamide }\end{array}$ & & $\begin{array}{l}\text { Suppresses T cell-dependent B-cell responses, } \\
\text { does not affect T-independent B-cell function }\end{array}$ & COX-2 inhibitor & [17] \\
\hline 5-amino-3-methyl-1,2-oxazole-4-carbohydrazide & & $\begin{array}{l}\text { Modulates T cell subset composition and the } \\
\text { levels of B cells in lymphoid organs, and } \\
\text { enhances anti-SRBC humoral immune } \\
\text { responses in mice }\end{array}$ & $\begin{array}{l}\text { Modulation of } \mathrm{T} \text { and } \mathrm{B} \text { cell content in } \\
\text { lymphatic organs }\end{array}$ & [18] \\
\hline $\begin{array}{l}\text { 06K/2-(5-amino-3-methyl-1,2-oxazole-4-carbonyl)- } \mathrm{N} \text { - } \\
\text { (4-chlorophenyl)hydrazine-1-carbothioamide }\end{array}$ & & $\begin{array}{l}\text { Induces lymphopoiesis and the generation of } \\
\text { regulatory T-cells, stimulates the humoral } \\
\text { immune response, decreases the DTH } \\
\text { reaction }\end{array}$ & $\begin{array}{l}\text { Increases percentage of CD } 8+\text { and } \\
\text { regulatory CD } 4+C D 25+F o x 3+T \text { cells in } \\
\text { spleens and lymph nodes }\end{array}$ & [19] \\
\hline $\begin{array}{l}\text { 01K/2-(5-amino-3-methyl-1,2-oxazole-4-carbonyl)- } N \text { - } \\
\text { phenylhydrazine-1-carbothioamide }\end{array}$ & & $\begin{array}{l}\text { Regulates proliferation of thymocytes, } \\
\text { splenocytes, and lymph node cells }\end{array}$ & $\begin{array}{l}\text { Regulation of IL- } 1 \beta \text { and TNF- } \alpha \text { production } \\
\text { in peritoneal cell cultures }\end{array}$ & [20] \\
\hline $\begin{array}{l}\text { MO5/5-amino-3-methyl- } N \text {-[(4-methylphenyl)methyl]- } \\
\text { 1,2-oxazole-4-carboxamide }\end{array}$ & & $\begin{array}{l}\text { Inhibits the humoral immune response } \\
\text { in vitro }\end{array}$ & Inhibition of $\mathrm{TNF} \alpha$ production & [14] \\
\hline \multicolumn{5}{|c|}{ Anti-inflammatory } \\
\hline $\begin{array}{l}\text { 5-amino- } N \text {-(4-ethoxyphenyl)-3-methyl-1,2-oxazole- } \\
\text { 4-carboxamide }\end{array}$ & & $\begin{array}{l}\text { Lowers carrageenan-induced paw edema, } \\
\text { exhibits antibacterial activity }\end{array}$ & N.D. & [21] \\
\hline
\end{tabular}


Table 1. Cont.

\begin{tabular}{|c|c|c|c|c|}
\hline Compound & Structure & Activity & Molecular/Cellular Mechanism of Action & Reference Number \\
\hline $\begin{array}{l}\text { 5-benzamido-N-(4-chlorophenyl)-3-methyl-1,2-oxazole- } \\
\text { 4-carboxamide }\end{array}$ & & $\begin{array}{l}\text { Shows anti-inflammatory activity in the } \\
\text { carrageenan-induced reaction, has } \\
\text { antibacterial properties }\end{array}$ & N.D. & [21] \\
\hline $\begin{array}{l}\text { VGX-1027 (S,R)-(3-phenyl-4,5-dihydro-1, } \\
\text { 2-oxazol-5-yl)acetic acid }\end{array}$ & & $\begin{array}{l}\text { Suppresses carrageenan-induced pleurisy, } \\
\text { LPS-induced lethality, and type } \\
\text { II-collagen-induced arthritis }\end{array}$ & $\begin{array}{l}\text { Suppression of TNF } \alpha, \text { IL-1 } \beta, \text { MIF, } \\
\text { inhibition of NFKB and p38, and } \\
\text { upregulation of ERK signaling }\end{array}$ & [22] \\
\hline $\begin{array}{l}N \text {-(2-(Benzo[d][1,3]dioxol-5-yl)ethyl)-5-(biphen-4- } \\
\text { yl)-isoxazole-3-carboxamide }\end{array}$ & & Protects against experimental colitis & $\begin{array}{l}\text { Inhibition of FAAH (fatty acid amide } \\
\text { hydrolase)) }\end{array}$ & [23] \\
\hline $\begin{array}{l}\text { 2b/5-(3-methylthiophen-2-yl)-3-(3,4,5- } \\
\text { trimethoxyphenyl)-1,2-oxazole }\end{array}$ & & $\begin{array}{l}\text { Inhibits tumor growth, peritoneal } \\
\text { angiogenesis, and ascite formation in Erlich } \\
\text { carcinoma mouse model }\end{array}$ & $\begin{array}{l}\text { Inhibitory activity toward lipooxygenase } \\
\text { (LOX) and COX-2 }\end{array}$ & [24] \\
\hline $\begin{array}{l}\text { 39/4-(4-Chlorophenyl)-5-[4-(quinolin-2-ylmethoxy) } \\
\text { phenyl]isoxazol-3-carboxylic acid } \\
\text { 40/4-(4-Chlorophenyl)-5-[4-(benzothiazol-2 } \\
\text {-ylmethoxy)phenyl] } \\
\text { isoxazol-3-carboxylic acid }\end{array}$ & & Anti-inflammatory agent & $\begin{array}{l}\text { Inhibitory activity against cellular 5-LO } \\
\text { (5-lipoxygenase) product synthesis }\end{array}$ & [25] \\
\hline $\begin{array}{l}\text { ISO-1/(S,R)-methyl [3-(4-oxocyclohexa-2, } \\
\text { 5-dien-1-ylidene)-1,2-oxazolidin-5-yl]acetate }\end{array}$ & & $\begin{array}{l}\text { Blocks corticosteroid-insensitive lung } \\
\text { inflammation and airway } \\
\text { hyper-responsiveness) suppresses lung } \\
\text { inflammation in ozone-exposed mice, in } \\
\text { contrast to dexamethasone }\end{array}$ & $\begin{array}{l}\text { Inhibition of migration inhibitory factor } \\
\text { (MIF) function }\end{array}$ & [26] \\
\hline
\end{tabular}


Table 1. Cont

\begin{tabular}{|c|c|c|c|c|}
\hline Compound & Structure & Activity & Molecular/Cellular Mechanism of Action & Reference Number \\
\hline $\begin{array}{c}\text { Cpd } \\
\text { \#15/(16S,17R)-30-bromo-6,9-difluoro-11b,21- } \\
\text { dihydroxy-40H-pregna-1,4-dieno[16,17- } d] \\
\text { isoxazole-3,20-dione }\end{array}$ & & $\begin{array}{l}\text { Inhibits eosinophilic infiltration in a model of } \\
\text { allergen-induced pulmonary inflammation } \\
\text { in rats }\end{array}$ & $\begin{array}{l}\text { Inhibits LPS-induced nitric oxide } \\
\text { production }\end{array}$ & [27] \\
\hline $\begin{array}{l}\text { 7a/N-(4-(isoxazol-5-yl)phenyl)-4,6-di(piperidin-1-yl)- } \\
\text { 1,3,5-triazin-2-amine }\end{array}$ & & $\begin{array}{l}\text { Reduces carrageenan-induced mice paw } \\
\text { edema in comparison to celecoxib }\end{array}$ & COX-2 inhibitor & [28] \\
\hline $\begin{array}{l}\text { MZO-2/ethyl } \\
\text { N-(4-\{[(2,4-dimethoxyphenyl)methyl]carbamoyl\}-3- } \\
\text { methyl-1,2-oxazol-5-yl)ethanimidate }\end{array}$ & & $\begin{array}{l}\text { Inhibits carrageenan-induced footpad } \\
\text { inflammation and the contact sensitivity in } \\
\text { mice to oxazolone when applied in ointment }\end{array}$ & $\begin{array}{l}\text { Suppression of LPS-induced TNF } \alpha \text {, and } \\
\text { the expression of caspases } 3,8 \text {, and } 9 \text { in } \\
\text { Jurkat cells }\end{array}$ & [29] \\
\hline $\begin{array}{l}\text { 4-(2-(4-(1H-benzimidazol-2-yl)phenyl)hydrazono)-1- } \\
\text { (4-chlorophenyl)-3-methyl-1H-pyrazol-5(4H)-one }\end{array}$ & & $\begin{array}{l}\text { Demonstrates analgesic activity and } \\
\text { protection in paw edema test, is comparable } \\
\text { with that of the reference drug Diclofenac }\end{array}$ & N.D. & [30] \\
\hline Isoxazole-mercaptobenzimidazole hybrids & & $\begin{array}{l}\text { Is analgesic and anti-inflammatory activity } \\
\text { in vivo }\end{array}$ & N.D. & [31] \\
\hline $\begin{array}{l}\text { (3S,3aR,6aS)-5-benzyl-3-(1H-indol-3-yl)-2- } \\
\text { phenyl-hexahydro-2H-pyrrolo[3,4-d][1,2] oxazole-4, } \\
\text { 6-dione }\left(\mathbf{9}^{\mathrm{a}}\right)\end{array}$ & & Increases survival in a mouse model of sepsis & $\begin{array}{l}\text { Inhibition of LPS-induced TNF } \alpha \text { and IL-6 } \\
\text { production in macrophage THP-1 cells }\end{array}$ & [32] \\
\hline
\end{tabular}


Table 1. Cont.

\begin{tabular}{|c|c|c|c|c|}
\hline Compound & Structure & Activity & Molecular/Cellular Mechanism of Action & Reference Number \\
\hline \multicolumn{5}{|c|}{ Immunostimulatory } \\
\hline $\begin{array}{l}\text { HAB-439/(3-phenyl-4,5-dihydro-1,2-oxazol-5- } \\
\text { yl)phosphonic acid }\end{array}$ & & $\begin{array}{l}\text { Stimulates DTH response to Salmonella } \\
\text { typhimurium and Listeria monocytogenes }\end{array}$ & Inhibitor of aminopeptidase B & [33] \\
\hline $\begin{array}{l}\text { RM-11/3,5-dimethyl-5,6-dihydro-4H-[1,2] oxazolo } \\
{[5,4-e][1,2,4] \text { triazepin-4-one }}\end{array}$ & & $\begin{array}{l}\text { Stimulates mitogen-induced splenocyte } \\
\text { proliferation and accelerates the restoration } \\
\text { of the humoral and cellular immune } \\
\text { response in cyclophosphamide-treated mice }\end{array}$ & N.D. & {$[34,35]$} \\
\hline $\begin{array}{l}\text { R-11/3,5-dimethyl-5,8-dihydro-4H-[1,2] oxazolo } \\
{[5,4-e][1,2,4] \text { triazepin-4-one }}\end{array}$ & & $\begin{array}{l}\text { Recruits CD19+ B and accelerates the } \\
\text { development of both types of the immune } \\
\text { response in immunocompromised mice }\end{array}$ & $\begin{array}{l}\text { Stimulation of LPS-induced IL-6 } \\
\text { production in human whole blood cultures }\end{array}$ & [36] \\
\hline $\begin{array}{l}\text { R-13/3,5-dimethyl-5,8-dihydro-4H-[1,2]oxazolo } \\
{[5,4-e][1,2,4] \text { triazepin-4-one hydrochloride }}\end{array}$ & & $\begin{array}{l}\text { Recruits } \mathrm{CD} 4+\mathrm{T} \text { cells and accelerates the } \\
\text { restoration of both types of the immune } \\
\text { response in immunocompromised mice }\end{array}$ & N.D. & [37] \\
\hline $\begin{array}{l}\text { M4/.2-(5-amino-3-methyl-1,2-oxazole-4-carbonyl)- } \\
\text { N-(prop-2-en-1-yl)hydrazine-1-carbothioamide }\end{array}$ & & $\begin{array}{l}\text { Enhances the mitogen-induced proliferative } \\
\text { response of human PBMC }\end{array}$ & N.D. & [12] \\
\hline 5-amino-3-methyl-1,2-oxazole-4-carbohydrazide & & $\begin{array}{l}\text { Stimulates mitogen-induced proliferation of } \\
\text { splenocytes and lymph node cells }\end{array}$ & $\begin{array}{l}\text { Increase of LPS-induced induced IL- } 1 \beta \\
\text { production by peritoneal cells }\end{array}$ & [38] \\
\hline $\begin{array}{l}\text { 8e/3-(4-methoxyphenyl)-4(3-hydroxy-4- } \\
\text { carboxybenzoyl)-5-(3-chlorophenyl)-4, } \\
\text { 5-dihydrodihydroisoxazoline }\end{array}$ & & $\begin{array}{l}\text { Augments the proliferative response of } \\
\text { human and mouse lymphocytes }\end{array}$ & Increased IL-2 secretion & [39] \\
\hline
\end{tabular}

${ }^{*}$ Recently established, unpublished; N.D.—not defined. 


\section{Results and Discussion}

\subsection{Immune Suppression}

Leflunomide and its active metabolite [6] are the most well-recognized immunosuppressive drugs, and they have found therapeutic applications if used alone or in combination with other drugs in rheumatoid arthritis [40] or transplantation [41]. As a prime representative of the isoxazole family, the drug is widely used as a reference drug to compare the potency of other investigated isoxazoles. Another example of a widely used isoxazole drug is Parecoxib, a pain reliever that acts as cyclooxygenase 2 (COX-2) inhibitor [7]. Its safety has been a subject of many multicenter trials, as summarized in a recent article [42], which could not definitely confirm the lack of its side effects reported earlier [43].

In investigations with rodents, a number of isoxazole derivatives was evaluated for their in vitro and in vivo immunosuppressive activities. In a study on the derivatives of isoxazole[4,5- $d$ ] pyrimidine [8], two compounds, $\mathbf{8 g}$ and 10f, inhibited the humoral immune response to sheep erythrocytes (SRBC) in vivo, but only one of them suppressed (10f) the delayed-type hypersensitivity response (DTH), showing that closely related compounds may differentially affect these two major types of immune response.

Suppressive properties of 5-amino-3-methylisoxazole-4-carboxylic acid amides and ureilenes [44], and 5-aminomethinimino-3-methyl-4-isoxazolecarboxylic acid phenylamides [9] on the humoral and cellular immune response in mice were subsequently found. One of the compounds, 5-(2-hydroxyethyl)piperazinomethinimino-3-methyl-4-isoxazolecarboxylic acid 4-(4-ethoxyphenyl)-amide (4d) [9] exhibited an exceptionally strong level of activity, comparable to cyclosporine. In turn, a study on the immunosuppressive activities of 5-substituted 3-methylisoxazole[5,4- $d$ ]-1,2,3-triazin-4-one derivatives [45], was supplemented with quantum-chemical calculations using AM1, a semi-empirical method for geometry optimization, the estimation of descriptor values, and the localization of the HOMO and LUMO orbital. The structure/activity investigations were extended by the application of the B3LYP hybrid exchange-correlation energy functional and the $6-31 \mathrm{G}(\mathrm{d}, \mathrm{p})$ basis set. [46] The Polarizable Continuum (SCRF/PCM) solvent model was also taken into account, in order to show the solvent influence on the electron density, and the electrostatic potential around the exemplary molecules. Correlations between the molecular structure and its biological properties were subsequently found by using a stepwise selection of scales for the multiple linear regression (MLR).

The studies on an isoxazole[5,4-e]triazepine derivative (compound RM33) led us to a demonstration of the very potent immunosuppressive activities of the compound in mouse models $[10,47]$. The compound effectively suppressed both the humoral response to SRBC, and the cellular response to ovalbumin (OVA) when administered intraperitoneally or per os. The compound could also act locally by the inhibition of foot pad edema when admixed with Freund's complete adjuvant. In addition, serum tumor necrosis factor alpha (TNF $\alpha$ ) and interleukin 6 (IL-6) levels, induced by administration of lipopolysaccharide (LPS) were reduced, but not an inducible interleukin 10 (IL-10) concentration in splenocyte cultures. RM33 inhibited also foot pad edema that was induced by carrageenan in Wistar rats [48], accompanied by lower serum TNF $\alpha$ levels. The inhibition of the foot pad edema was correlated with adequate histological changes, such as a lesser level of damage to mast cells, and smaller macrophage infiltration. Very recent (unpublished data) indicate that the immunosuppressive action of RM33 may consist of its apoptotic action on thymocytes and splenocytes, associated with strong increases of caspase 9, p53, and NFkB1 and NFkB2 expression.

In another investigation of our group, a series of 5-amino-3-methylisoxazole[5,4- $d$ ]pyrimidin-4-one derivatives were obtained by the reaction of $N^{\prime}$-substituted derivatives of 5-amino-3-methyl-1,2-oxazole-4-carbohydrazide with ethyl orthoformate [11]. The compounds differentially inhibited in vivo cellular and humoral immune responses in mice and pokeweed mitogen (PWM)-induced polyclonal antibody production in a culture of human peripheral 
blood mononuclear cells (PBMC). The derivatives displayed differential inhibitory activities in these models, depending on the character and location of the substituted groups. Also, a significant suppression of the in vivo humoral immune response to SRBC in mice was achieved upon low doses of 5-amino-3-methyl-4-isoxazolecarboxylic acid semicarbazides and thiosemicarbazides [12]. Other studies on new lead structures of the isoxazole system [13] revealed their strong immunosuppressive activities in the humoral immune response, the carrageenan model, and the proliferative response of lymphocytes. Density Functional Theory (DFT) was employed to shed light on the molecular properties of the investigated compounds. The geometrical parameters of the studied molecular structures were fully optimized at the B3LYP/6-311G $(\mathrm{d}, \mathrm{p})$ level. The atomic charge distribution, derived on the basis of the Mulliken population analysis, was correlated with the immunological activity of the compounds. The obtained relationships revealed that the isoxazole ring played an important role in the observed immunological activities.

In a study on 5-amino-3-methyl-4 isoxazolecarboxylic acid benzylamides [14] a selected MO5 compound (5-amino-3-methyl- $\mathrm{N}$-[(4-methylphenyl)methyl]-1,2-oxazole-4-carboxamide) inhibited the humoral immune response in vitro and stimulated the inductive phase of DTH in vivo, although it suppressed the eliciting phase of that response and the foot pad carrageenan reaction. Its action on phytohemagglutinin A (PHA)-induced PBMC proliferation, and TNF $\alpha$ production was also inhibitory. In a parallel study [15], effects of 5-amino-3-methyl-1,2-oxazole-4-carbohydrazide on selective gene expression in Caco-2 cells were studied, together with Leflunomide (5-methyl- $N$-[4-(trifluoromethyl)phenyl]-4-isoxazolecarboxamide), as a reference drug. It appeared that both compounds similarly regulated selected genes i.e., the upregulation of fractalkine (CX3CL1) and IL-17F, and the downregulation of IL-10 and toll-like receptor 4 (TLR4). Nevertheless, the expression of 12 genes was differently regulated by these compounds: interleukins (IL) IL-1B, IL-6, and a chemokine CCL22 were upregulated by the compound, but significantly suppressed by Leflunomide. IL-2 and IL-27 in turn were upregulated by Leflunomide and suppressed by the compound. The authors concluded that the studied compound has a potential for further modifications as an immunosuppressive agent, with applications that are different from that of Leflunomide.

In a new series of $N^{\prime}$-substituted derivatives of 5-amino- $N, 3$-dimethyl-1,2-oxazole-4carbohydrazide [16], a selected 5-amino- $N^{\prime}$-[2-(2,4-dihydroxyphenyl)ethylidene]- $N, 3$-dimethyl-1,2oxazole-4-carbohydrazide (MM3 compound) lowered the PHA-induced proliferation of PBMC and LPS-induced TNF $\alpha$ production in human blood cell culture. In the model of Jurkat cells, MM3 elicited strong increases in the expression of caspases, Fas, and NF- $\mathrm{kB1}$, indicating that a proapoptotic action may account for its immunosuppressive action in the studied models.

\subsection{Inhibition of Inflammation}

Izoxazole derivatives exhibiting anti-inflammatory properties constitute a major group from this class of potential therapeutics. In an early study [21] the authors demonstrated strong anti-inflammatory and antibacterial activity of $p$-etoxyphenylamid and $p$-chlorophenylamid of 5-benzoylamino-3-methyl-4-isoxazolecarboxylic acid. The most potent activity of these compounds were attributed to the benzoyl group in position 5 of the isoxazole ring.

HWA-486 (5-methyl- $N$-[4-(trifluoromethyl)phenyl]-1,2-oxazole-4-carboxamide), together with cyclophosphamide, a reference drug, was investigated in the model of adjuvant arthritis in Lewis rats [17]. The compound prevented the development of the disease and suppressed the mitogen-elicited proliferation of lymphocytes derived from adjuvant arthritis rats. In contrast to cyclophosphamide, the compound did not affect the proliferation of lymphocytes from healthy rats.

Leflunomide and its active metabolite A771726 [49] suppressed the immune response by means of various mechanisms [50,51]. In a model of J774.2 macrophages treated with LPS, both agents were shown to inhibit PGE2 accumulation in cell cultures. Further, in a whole blood human cell culture stimulated with calcium ionophore, Leflunomide inhibited both COX-1 and COX-2 activity [50]. In vivo effects of the compound were restricted by experimental substrate supply, and probably by 
plasma binding. Other important actions of A771726 include suppression of proinflammatory cytokine production, such as TNF $\alpha$ and IL-1 [51].

In an extensive study on in vitro, ex vivo, and in vivo immunopharmacological effects of VGX-1027 (S,R)-(3-phenyl-4,5-dihydro-1,2-oxazol-5-yl)acetic acid [22], the investigators evaluated the potential efficacy of the compound in the amelioration of acute and chronic immunoinflammatory diseases, based on its ability to inhibit LPS-induced cell signaling pathways. A lack of toxicity predisposes the compound for further preclinical investigations.

A potential utility of new fatty acid amine hydrolase (FAAH) inhibitors based on 3carboxamido-5-aryl-isoxazole scaffolds in protection against experimental colitis was recently also proposed [23].

A search for novel anticancer drug via inhibition of LOX and COX enzymes constitutes an important strategy, since the overproduction of leukotrienes and prostaglandins contributes to tumor growth by inducing formation of new blood vessels that support tumor cell growth. It was demonstrated [24] that one of the synthesized compounds, 5-(3-methylthiophen-2-yl)-3-(3,4,5-trimethoxyphenyl)-1,2-oxazole (2b) exhibited significant inhibitory activity toward lipooxygenase (LOX) and COX-2. 4,5-diarylisoxazol-3-carboxylic acids could also serve as leukotriene synthesis inhibitors [25], and thus they are potential anti-inflammatory drugs.

Macrophage migration inhibitory factor (MIF) is an inflammatory cytokine that is associated with inflammatory disorders, as only cytokine is resistant to steroid action. Airway hyper-responsiveness is also relatively resistant to steroid therapy. A MIF antagonist $(S, R)$-methyl [3-(4-oxocyclohexa-2,5-dien-1-ylidene)-1,2-oxazolidin-5-yl]acetate (ISO-1) [26] proved to be efficient in the suppression of lung inflammation in ozone-exposed mice, in contrast to Dexamethasone. MIF is also implicated in development of autoimmunity, so that the therapeutic efficacy of ISO-1 was also evaluated in a model of glomerulonephritis in lupus-prone NZB/NZW F1 and MLR/lpr mice [52]. The results showed that ISO-1, like anti-MIF, inhibited the interaction between MIF and its receptor, and reduced the functional and histological parameters of glomerulonephritis, leukocyte recruitment, proinflammatory cytokine and chemokine expression. These data support the therapeutic value of the compound by the downregulation of MIF-dependent pathways of tissue damage in systemic lupus erythematosus. For the prevention of another type of autoimmunity, (S,R)-(3-phenyl-4,5-dihydro-1,2-oxazol-5-yl)acetic acid (VGX-1027) was tested in a model of NOD mice, with spontaneous or accelerated forms of diabetes induced either by injection of cyclophosphamide or by transfer of spleen cells from acutely diabetic syngeneic donors, representing a preclinical model of human type 1 diabetes mellitus [53]. The compound significantly diminished the cumulative incidence of diabetes and insulitis in this model. The animals receiving VGX-1027 exhibited reduced production of the proinflammatory mediators, such as TNF $\alpha, \mathrm{IL}-1 \beta$, and MIF as well as inducible nitric-oxide synthase-mediated nitric oxide generation in both pancreatic islets and peripheral organs. The authors recommended VGX-1027 for further investigations as a prime candidate to treat this type of the autoimmune disease.

To suppress pulmonary inflammation, a novel glucocorticoids series of (GCs), $6 \alpha, 9 \alpha$-di-fluoro 3-substituted C-16,17-isoxazolines was designed [27]. A selected Cpd \#15 compound inhibited LPS-induced nitric oxide release in Raw264.7 mouse macrophages, and TNF $\alpha$-induced IL-8 production in human airway smooth muscle cells with a potency higher than that of Dexamethasone. The authors concluded that the compound displayed a pharmacokinetic and pharmacodynamic profile that was suitable for topical treatment of conditions that are associated with lung inflammatory reactions.

A series of new isoxazole derivatives of expected immunosuppressive activities was synthesized [29]. Following in vitro screening in the human cell models, the activity of a most active MZO-2 compound (ethyl $N$ - $(4-\{[(2,4-$ dimethoxyphenyl)methyl]carbamoyl\}-3-methyl-1,2-oxazol-5-yl)ethanimidate) in mouse in vivo models was evaluated. The compound, administered intraperitoneally, inhibited carrageenan-induced footpad edema, and the contact sensitivity in mice to oxazolone when applied in ointment, with a 
potency that was comparable to tacrolimus (Protopic ${ }^{\circledR}$ ). The compound inhibited also expression of caspases 3, 8, and 9 in Jurkat cells.

Several new 3-methylisoxazol-5(4H)-one/2-hydroxy/mercapto-6-methylpyrimidin-4(5H)-one/3 -methyl-1-substituted-1H-pyrazol-5(4H)-one substituted benzimidazole derivatives [30], were synthesized. A most potent representative of this series, 4-(2-(4-(1H-benzimidazol-2-yl) phenyl)hydrazono)-1-(4-chlorophenyl)-3-methyl-1H-pyrazol-5(4H)-one demonstrated significant analgesic activity, protection in carrageenan-induced footpad edema, efficient antibacterial, and moderate antiviral activities. Among the triazines, novel series [28] were synthesized, including isoxazoles with COX-2 inhibitory activity. To evaluate their anti-inflammatory activities, the compounds were investigated by the paw thickness inhibition assay. The most potent compound in the group of isoxazole derivatives that reduced the carrageenan-induced mice paw edema in comparison to Celecoxib, was compound 7a ( $N$-(4-(isoxazol-5-yl)phenyl)-4,6-di(piperidin-1-yl)-1,3,5-triazin-2-amine) (51\% inhibition of paw edema). Most of the compounds were even more potent than the reference drugs, such as: Celecoxib, Diclofenac, and Indomethacin. Analgesic and anti-inflammatory properties were also found when investigating isoxazole-mercaptobenzimidazole hybrids [31].

Indolyl-isoxazolidines are another category of compounds with potent anti-inflammatory-analgesic activities [32]. A selected compound, 9a, significantly inhibited LPS-induced TNF $\alpha$ and IL- 6 production in macrophage THP- 1 cells. The compound also caused analgesia and showed anti-inflammatory effects in the carrageenan test, with a potency that was comparable to that of indomethacin. Compound $9 \mathbf{a}$ was also effective in the protection of LPS-induced death in mice, indicating its potential usefulness as an analgesic/anti-inflammatory drug.

\subsection{Immunoregulation}

Following demonstration of the suppressive effects of HWA-486 (Leflunomide) compound in adjuvant-induced arthritis in rats using cyclophosphamide, prednisolone, and cyclosporine $\mathrm{A}$ as reference drugs [17], the studies were extended by using several in vivo and ex vivo methods that were aimed at the elucidation of differences between the mechanisms of the actions of HWA-486 and of reference immunosuppressors. The authors came to a conclusion [17] that the compound has inhibitory activity on T-cell-dependent B-cell immune responses, yet it does not affect T-cell-independent B-cells; thus T-cell responsiveness may not be affected. Therefore, these findings may explain the disease-modifying activity of HWA-486 in adjuvant-induced arthritic rats.

Immunoregulatory actions were described in a series of reports on the derivatives of phenylamides of 5-amino-3-methyl-4-isoxazolecarboxylic acid [44]. The activities of the compounds in the proliferative response of PBMC to PHA, and in LPS-induced cytokine production in the PBMC cultures were differential. The stimulatory or inhibitory effects depended strongly on the origin and location of substituents in the phenyl ring, as supported by QSAR (Quantitative Structure-Activity Relationship) studies. Similar conclusions could be drawn from in vivo and in vitro investigations on 4-imino derivatives of the 5-amino-3-methyl-1,2-oxazole-4-carbohydrazide and 5-amino-3-methylisoxazole[5,4- $d$ ]-6,7-dihydropyrimidine in mouse models [54].

Immunoregulatory properties were also observed with derivatives of 5-amino-3-methyl-1,2-oxazole-4-carbohydrazide [18]. The compound exhibited modulatory effects on T-cell subsets and levels of B-cells in lymphoid organs, and enhanced anti-SRBC antibody production in mice. The authors suggest its potential use in the treatment of autoimmune diseases, infections, or as an adjuvant for boosting the efficacy of vaccines.

The immunoregulatory properties of 2-(5-amino-3-methyl-1,2-oxazole-4-carbonyl)- $N$-(4chlorophenyl)hydrazine-1-carbothioamide (06K compound) in mouse in vivo models were also investigated [19]. Interestingly, the actions of the compounds were differential, depending on a model used. The compound stimulated antibody production against SRBC, as measured by the numbers of antibody-forming cells, but the cellular immune response to 
OVA was decreased. Further, the compound significantly diminished carrageenan-induced foot pad edema. Phenotypic studies revealed that the immunoregulatory properties of the compound involved the mobilization of lymphopoiesis, and the generation of regulatory $\mathrm{T}$ cells. In another report with the application of in vitro models [20] 2-(5-amino-3-methyl-1,2-oxazole-4-carbonyl)-N-phenylhydrazine-1-carbothioamide (01K), and 2-(5amino-3-methyl-1,2-oxazole-4-carbonyl)-N-(4-chlorophenyl)hydrazine-1-carbothioamide (06K) exhibited regulatory activity in the proliferation tests using cells from the thymus, spleen, and lymph nodes, as well as in the effects of the compounds on IL- $1 \beta$, and the production of TNF- $\alpha$ in peritoneal cell cultures. These actions were associated with the different influence of the compounds on signaling protein expression in immature T cell Jurkat cell lines. Immunosuppressive isoxazole Leflunomide and a stimulatory $\mathbf{R M - 1 1}$ compound (1,7-dimethyl-8-oxo-1,2H-isoxazole[5,4-e]triazepine) were applied as reference drugs.

A study on the immunoregulatory properties of the selected 5-amino-3-methyl-4isoxazolecarboxylic acid benzylamides [14], and its selected derivative MO5 (5-amino3-methyl-N-[(4-methylphenyl)methyl]-1,2-oxazole-4-carboxamide), showed that the compounds inhibited the humoral immune response in vitro, stimulated the inductive phase of DTH in vivo, although it inhibited the eliciting phase of that response. The compound also inhibited the carrageenan skin reaction in mice, and inhibited LPS-induced TNF $\alpha$ production in human whole blood culture, as well as PHA-induced proliferation of PMBC.

\subsection{Immunostimulation}

Immunostimulatory actions of therapeutics are equally important as immunosuppressive ones, and they are invaluable in the restoration of immune functions in immunocompromised individuals that are subjected to antibiotics and chemotherapy. In a study with HAB-439 isoxazoline derivative the compound appeared to be an inhibitor of aminopeptidase [33]. HAB-439 stimulated the DTH response to Salmonella typhimurium and Listeria monocytogenes. It also restored a decreased DTH reaction that was caused by the ampicillin treatment of mice infected with L. monocytogenes.

Several immunostimulatory isoxazole derivatives were synthesized, and their potential therapeutic utility was evaluated by our research team. RM-11 (3,5-dimethyl5,6-dihydro-4H-[1,2]oxazolo[5,4-e][1,2,4]triazepin-4-one) was found to potently stimulate both humoral and cellular immune response to SRBC in mice [34]. The compound also stimulated ConA-induced splenocyte proliferation. RM-11 showed no sign of toxicity when given to mice at a dose of $250 \mathrm{mg} / \mathrm{kg}$ body weight. The compound was subsequently investigated in a model of immunocompromised mice treated with cyclophosphamide (CP) [35]. In this model, the compound, given i.p. in repeatable doses, caused a rapid recovery of both antibody production against SRBC and DTH responses to OVA, in comparison with control mice. In addition, the compound accelerated the process of myelopoiesis as measured by the percentage of neutrophils and their precursors in the peripheral blood. The compound was also protective in the humoral immune response in vitro to SRBS suppressed by methotrexate. The phenotypic studies revealed that RM-11 preferentially increased the percentage of mature, single positive CD4+ and CD8+ T cells in the spleen of normal mice. Similar results were obtained with another T-cell tropic isoxazole derivative, 3,5-dimethyl-5,8-dihydro-4H-[1,2]oxazolo[5,4-e][1,2,4]triazepin-4-one hydrochloride (R 13), which also induced a significant increase of CD4+ T cells in the spleen, and in the lymph nodes of mice [37]. The compound significantly accelerated both the antibody production and the cellular immune response. Unlike RM-11, this compound decreased the content of myelocytic cells in the circulating blood, but increased the level of immature lymphocyte forms, indicating the preferential promotion of lymphopoiesis in CP-treated mice. In contrast to the two previously described compounds, 3,5-dimethyl-5,8-dihydro-4H-[1,2]oxazolo[5,4-e][1,2,4]triazepin-4-one (R-11) appeared to preferentially induce the recruitment of CD19+ B cells in normal mice [36]. Moreover, the development of both the humoral immune response to SRBC and DTH to OVA was also accelerated 
in CP-immunocompromised mice by this compound. The compound also stimulated IL-6 production, elicited by LPS in human whole blood cultures. We postulate that the above described compounds may be invaluable in the restitution of the immune function of patients undergoing chemotherapy. At present, the only therapeutic that is accepted for this purpose is granulocyte colony stimulating factor $\left(\right.$ Filgrastim ${ }^{\circledR}$ ) [55]. However, the use of this cytokine has serious limitations, since it is costly and temperature-sensitive. In addition, this cytokine predominantly promotes myelopoiesis, the process is spontaneously recovered quickly [56]. However, the main problem with the reconstitution of the immune cell compartments of the chemotherapy patients are T- and B-cell compartments, where recovery takes much longer [57].

Other stimulatory izoxazole derivatives included 7-amino-3,5-dimethylisoxazole[5,4-e][1,3,4] -triazepin-4-one, showing the stimulatory effect on Con A-induced mouse splenocyte proliferation and cytokine production by the P388D1 macrophage cell line [58] and 2-(5-amino3-methyl-1,2-oxazole-4-carbonyl)- $N$-(prop-2-en-1-yl)hydrazine-1-carbothioamide (compound M4) [12], which stimulated PHA-induced proliferation of human PBMC.

The aim of another study was to determine the immunomodulatory activity of 5-amino-3-methyl-1,2-oxazole-4-carbohydrazide in vitro [38]. The compound was not cytotoxic against reference cell lines, up to a concentration of $200 \mu \mathrm{g} / \mathrm{mL}$. The compound stimulated the mitogen-induced proliferation of lymphocytes isolated from spleens and mesenteric lymph nodes when they were used alone and in combination with mitogens, and it increased LPS-elicited IL-1 $\beta$ production in peritoneal cell culture.

Interestingly, among salicylic acid derivatives containing an isoxazole ring, 3-(4methoxyphenyl)-4-(3-hydroxy-4-carboxybenzoyl)-5-(3-chlorophenyl)-4,5-dihydroisoxazoline (8e), which demonstrated mitogenic activity towards human lymphocytes and mouse splenocytes, was found [39]. The ability of the compound to stimulate cell division was caused by increased IL-2 secretion. It seems that an advantage of this new mitogenic compound is that it should not bind to and inactivate sugar-containing biologically active proteins, in contrast to lectins (ConA, PHA). A property of binding to sugars in biologically active glycoproteins like lactoferrin [59] by protein mitogens (lectins) may hamper the interpretation of results deriving from models where mitogenic lectins are applied.

\section{Conclusions}

The isoxazole derivatives described herein have differential activities and mechanisms of action, and it may be applied in such disease and immunological disorders as inflammation, infection, autoimmune disorders, and impaired immune responsiveness. It is worthy to underline that many of the compounds, presented in this review, have higher potency in comparison to relevant reference drugs; thus they are potential therapeutics and they may replace registered drugs. Alternatively, they may enrich the pool of existing drugs in the market. Keeping in mind that even registered drugs are not completely devoid of side-effects and toxicity, the search for new compounds with the possible highest selectivity of action and the lowest toxicity is highly justified.

Funding: This research was funded by Wroclaw Medical University, grant number STD090.17.012.

Conflicts of Interest: The authors declare no conflict of interest.

\section{References}

1. Giomi, D.; Cordero, F.M.; Machetti, F. Comprehensive Heterocyclic Chemistry III; Katrizky, A.R., Ramsden, C.A., Scriven, E.F.V., Taylor, R.J.K., Eds.; Elsevier: Oxford, UK, 2008; pp. 365-486.

2. Barmade, M.A.; Murumkar, P.R.; Sharma, M.K.; Yadav, M.R. Medicinal chemistry perspective of fused isoxazole derivatives. Curr. Top. Med. Chem. 2016, 16, 2863-2883. [CrossRef] [PubMed]

3. Uto, Y. 1, 2-Benzisoxazole: A privileged structure with a potential for polypharmacology. Curr. Pharm. Des. 2016, 22, 3201-3211. [CrossRef] [PubMed] 
4. Sysak, A.; Obmińska-Mrukowicz, B. Isoxazole ring as a useful scaffold in a search for new therapeutic agents. Eur. J. Med. Chem. 2017, 137, 292-309. [CrossRef] [PubMed]

5. Zhu, J.; Mo, J.; Lin, H.Z.; Chen, Y.; Sun, H.P. The recent progress of isoxazole in medicinal chemistry. Bioorg. Med. Chem. 2018, 23, 3065-3075. [CrossRef] [PubMed]

6. Herrmann, M.L.; Schleyerbach, R.; Kirschbaum, B.J. Leflunomide: An immunomodulatory drug for the treatment of rheumatoid arthritis and other autoimmune diseases. Immunopharmacology 2000, 47, 273-289. [CrossRef]

7. Satyanarayana, P.S.; Jain, N.K.; Singh, S.; Kulkarni, S.K. Effect of selective inhibition of cyclooxygenase-2 on lipopolysaccharide-induced hyperalgesia. Inflammopharmacology 2004, 12, 57-68. [CrossRef] [PubMed]

8. Wagner, E.; Al-Kadasi, K.; Zimecki, M.; Sawka-Dobrowolska, W. Synthesis and pharmacological screening of derivatives of isoxazolo[4,5-d]pyrimidine. Eur. J. Med. Chem. 2008, 43, 2498-2504. [CrossRef] [PubMed]

9. Ryng, S.; Machoń, Z.; Wieczorek, Z.; Zimecki, M.; Głowiak, T. Synthesis and structure elucidation of 5-aminomethinimino-3-methyl-4-isoxazolecarboxylic acid phenylamides and their immunological activity. Arch. Pharm. 1997, 330, 319-326. [CrossRef]

10. Ryng, S.; Zimecki, M.; Maczyński, M.; Chodaczek, G.; Kocieba, M. Immunosuppressive activity of an isoxazolo[5,4-e]triazepine-Compound RM33. I. Effects on the humoral and cellular immune response in mice. Pharmacol. Rep. 2005, 57, 195-202. [PubMed]

11. Maczyński, M.; Zimecki, M.; Drozd-Szczygieł, E.; Ryng, S. The synthesis, physicochemical properties and immunological activity of 5-amino-3-methylisoxazolo[5,4-d]4-pyrimidinone derivatives. Cell. Mol. Biol. Lett. 2005, 10, 613-623. [PubMed]

12. Maczyński, M.; Zimecki, M.; Taraszkiewicz, M.; Ryng, S. Synthesis, immunological activity and computational study of 5-amino-3-methyl-4-isoxazolecarboxylic acid semicarbazides and thiosemicarbazides. Acta Pol. Pharm. 2008, 65, 543-549. [PubMed]

13. Maczyński, M.; Ryng, S.; Artym, J.; Kocieba, M.; Zimecki, M.; Brudnik, K.; Jodkowski, J.T. New lead structures in the isoxazole system: Relationship between quantum chemical parameters and immunological activity. Acta Pol. Pharm. 2014, 71, 71-83. [PubMed]

14. Maczyński, M.; Artym, J.; Kocieba, M.; Sochacka-Ćwikła, A.; Drozd-Szczygieł, E.; Ryng, S.; Zimecki, M. Synthesis and immunoregulatory properties of selected 5-amino-3-methyl-4 isoxazolecarboxylic acid benzylamides. Acta Pol. Pharm. 2016, 73, 1201-1211. [PubMed]

15. Płoszaj, P.; Regiec, A.; Ryng, S.; Piwowar, A.; Kruzel, M.L. Influence of 5-amino-3-methyl4-isoxazolecarbohydrazide on selective gene expression in Caco-2 cultured cells. Immunopharmacol. Immunotoxicol. 2016, 38, 486-494. [CrossRef] [PubMed]

16. Mączyński, M.; Borska, S.; Mieszała, K.; Kocięba, M.; Zaczyńska, E.; Kochanowska, I.; Zimecki, M. Synthesis, immunosuppressive properties, and mechanism of action of a new isoxazole derivative. Molecules 2018, 23, 1545. [CrossRef] [PubMed]

17. Bartlett, R.R.; Schleyerbach, R. Immunopharmacological profile of a novel isoxazol derivative, HWA 486 , with potential antirheumatic activity-I. Disease modifying action on adjuvant arthritis of the rat. Int. J. Immunopharmacol. 1985, 7, 7-18. [CrossRef]

18. Drynda, A.; Obmińska-Mrukowicz, B.; Mączyński, M.; Ryng, S. The effect of 5-amino-3-methyl4-isoxazolecarboxylic acid hydrazide on lymphocyte subsets and humoral immune response in SRBC-immunized mice. Immunopharmacol. Immunotoxicol. 2015, 37, 148-157. [CrossRef] [PubMed]

19. Drynda, A.; Obmińska-Mrukowicz, B.; Zaczyńska, E.; Zimecki, M.; Ryng, S.; Mączyński, M. Immunoregulatory effects of 4-(4-chlorophenyl)-1-(5-amino-3-methylisoxazole-4-carbonyl)-thiosemicarbazide (06K) in non-immunized and SRBC-immunized mice. J. Pharm. Pharmacol. 2016, 68, 1613-1620. [CrossRef] [PubMed]

20. Drynda, A.; Obmińska-Mrukowicz, B.; Zaczyńska, E.; Zimecki, M.; Kochanowska, I.; Ryng, S.; Mączyński, M. 5-Amino-3-methyl-4-isoxazolecarboxylic acid hydrazide derivatives with in vitro immunomodulatory activities. Chem. Biol. Drug Des. 2017, 89, 705-713. [CrossRef] [PubMed]

21. Machoń, Z.; Ryng, S. Synthesis and biological properties of 5-benzoylamino-3-methyl-4-isoxazolocarboxylic acid derivatives. Arch. Immunol. Ther. Exp. 1981, 29, 813-821. 
22. Stojanovic, I.; Cuzzocrea, S.; Mangano, K.; Mazzon, E.; Miljkovic, D.; Wang, M.; Donia, M.; Al Abed, Y.; Kim, J.; Nicoletti, F.; et al. In vitro, ex vivo and in vivo immunopharmacological activities of the isoxazoline compound VGX-1027: Modulation of cytokine synthesis and prevention of both organ-specific and systemic autoimmune diseases in murine models. Clin. Immunol. 2007, 123, 311-323. [CrossRef] [PubMed]

23. Andrzejak, V.; Muccioli, G.G.; Body-Malapel, M.; El Bakali, J.; Djouina, M.; Renault, N.; Chavatte, P.; Desreumaux, P.; Lambert, D.M.; Millet, R. New FAAH inhibitors based on 3-carboxamido-5-aryl-isoxazole scaffold that protect against experimental colitis. Bioorg. Med. Chem. 2011, 19, 3777-3786. [CrossRef] [PubMed]

24. Rakesh, K.S.; Jagadish, S.; Balaji, K.S.; Zameer, F.; Swaroop, T.R.; Mohan, C.D.; Jayarama, S.; Rangappa, K.S. 3,5-disubstituted isoxazole derivatives: Potential inhibitors of inflammation and Cancer. Inflammation 2016, 39, 269-280. [CrossRef] [PubMed]

25. Banoglu, E.; Çelikoğlu, E.; Völker, S.; Olgaç, A.; Gerstmeier, J.; Garscha, U.; Çalışkan, B.; Schubert, U.S.; Carotti, A.; Macchiarulo, A.; Werz, O. 4,5-diarylisoxazol-3-carboxylic acids: A new class of leukotriene biosynthesis inhibitors potentially targeting 5-lipoxygenase-activating protein (FLAP). Eur. J. Med. Chem. 2016, 4, 1-10. [CrossRef] [PubMed]

26. Russell, K.E.; Chung, K.F.; Clarke, C.J.; Durham, A.L.; Mallia, P.; Footitt, J.; Johnston, S.L.; Barnes, P.J.; Hall, S.R.; Simpson, K.D.; et al. The MIF antagonist ISO-1 attenuates corticosteroid-insensitive inflammation and airways hyperresponsiveness in an ozone-induced model of COPD. PLoS ONE 2016, 11, 0146102. [CrossRef] [PubMed]

27. Ghidini, E.; Capelli, A.M.; Carnini, C.; Cenacchi, V.; Marchini, G.; Virdis, A.; Italia, A.; Facchinetti, F. Discovery of a novel isoxazoline derivative of prednisolone endowed with a robust anti-inflammatory profile and suitable for topical pulmonary administration. Steroids 2015, 95, 88-95. [CrossRef] [PubMed]

28. Elshemy, H.A.H.; Abdelall, E.K.A.; Azouz, A.A.; Moawad, A.; Ali, W.A.M.; Safwat, N.M. Synthesis, anti-inflammatory, cyclooxygenases inhibitions assays and histopathological study of poly-substituted 1,3,5-triazines: Confirmation of regiospecific pyrazole cyclization by HMBC. Eur. J. Med. Chem. 2017, 127, 10-21. [CrossRef] [PubMed]

29. Mączyński, M.; Artym, J.; Kocięba, M.; Kochanowska, I.; Ryng, S.; Zimecki, M. Anti-inflammatory properties of an isoxazole derivative-MZO-2. Pharmacol. Rep. 2016, 68, 894-902. [CrossRef] [PubMed]

30. Chikkula Krishna, V.; Sundararajan, R. Analgesic, anti-inflammatory, and antimicrobial activities of novel isoxazole/pyrimidine/pyrazole substituted benzimidazole analogs. Med. Chem. Res. 2017, 26, 3026-3037. [CrossRef]

31. Kankala, S.; Kankala, R.K.; Gundepaka, P.; Thota, N.; Nerella, S.; Gangula, M.R.; Guguloth, H.; Kagga, M.; Vadde, R.; Vasam, C.S. Regioselective synthesis of isoxazole-mercaptobenzimidazole hybrids and their in vivo analgesic and anti-inflammatory activity studies. Bioorg. Med. Chem. Lett. 2013, 23, 1306-1309. [CrossRef] [PubMed]

32. Singh, G.; Singh, G.; Bhatti, R.; Gupta, M.; Kumar, A.; Sharma, A.; Singh Ishar, M.P. Indolyl-isoxazolidines attenuate LPS-stimulated pro-inflammatory cytokines and increase survival in a mouse model of sepsis: Identification of potent lead. Eur. J. Med. Chem. 2018, 153, 56-64. [CrossRef] [PubMed]

33. Dickneite, G.; Schwab, W.; Schorlemmer, H.U.; Gebert, U.; Sedlacek, H.H. Effect of the new immunostimulator HAB 439 on cell-mediated immunity against intracellular bacteria. Int. J. Immunopharmacol. 1991, 13, 541-548. [CrossRef]

34. Ryng, S.; Sonnenberg, Z.; Zimecki, M. RM-11, a new izoxasole derivative, is a potent stimulator of the humoral and cellular immune responses in mice. Arch. Immunol. Ther. Exp. 2000, 48, 127-131.

35. Zimecki, M.; Artym, J.; Ryng, S.; Obmińska-Mrukowicz, B. RM-11, an isoxazole derivative, accelerates restoration of the immune function in mice treated with cyclophosphamide. Pharmacol. Rep. 2008, 60, 183-189. [PubMed]

36. Zimecki, M.; Artym, J.; Kocięba, M.; Obmińska-Mrukowicz, B.; Mączyński, M.; Ryng, S. Restoration of immune system function is accelerated in immunocompromised mice by the B-cell-tropic isoxazole R-11. Pharmacol. Rep. 2012, 64, 403-411. [CrossRef]

37. Zimecki, M.; Artym, J.; Kocięba, M.; Obmińska-Mrukowicz, B.; Macczyński, M.; Ryng, S. Immune function in cyclophosphamide-treated mice is restored by the T-cell-tropic isoxazole derivative R-13. J. Immunotoxicol. 2015, 12, 322-329. [CrossRef] [PubMed] 
38. Drynda, A.; Mączyński, M.; Ryng, S.; Obmińska-Mrukowicz, B. In vitro immunomodulatory effects of 5-amino-3-methyl-4-isoxazolecarboxylic acid hydrazide on the cellular immune response. Immunopharmacol. Immunotoxicol. 2014, 36, 150-157. [CrossRef] [PubMed]

39. Puttaswamy, N.; Pavan Kumar, G.S.; Al-Ghorbani, M.; Vigneshwaran, V.; Prabhakar, B.T.; Khanum, S.A. Synthesis and biological evaluation of salicylic acid conjugated isoxazoline analogues on immune cell proliferation and angiogenesis. Eur. J. Med. Chem. 2016, 114, 153-161. [CrossRef] [PubMed]

40. Kremer, J.M. Methotrexate and leflunomide: Biochemical basis for combination therapy in the treatment of rheumatoid arthritis. Semin. Arthritis Rheum. 1999, 29, 14-26. [CrossRef]

41. Furst, D.E. Innovative treatment approaches for rheumatoid arthritis. Cyclosporin, leflunomide and nitrogen mustard. Baillieres Clin. Rheumatol. 1995, 9, 711-729. [CrossRef]

42. Schug, S.A.; Parsons, B.; Li, C.; Xia, F. The safety profile of parecoxib for the treatment of postoperative pain: A pooled analysis of 28 randomized, double-blind, placebo-controlled clinical trials and a review of over 10 years of postauthorization data. J. Pain Res. 2017, 10, 2451-2459. [CrossRef] [PubMed]

43. Zhang, J.; Ding, E.L.; Song, Y. Adverse effects of cyclooxygenase 2 inhibitors on renal and arrhythmia events meta-analysis of randomized trials. J. Am. Med. Assoc. 2006, 296, 1619-1632. [CrossRef] [PubMed]

44. Ryng, S.; Machon, Z.; Wieczorek, Z.; Zimecki, M. Synthesis and immunological activity of new 5-amino-3-methyl 4-amido and 4-ureilene isoxazole derivatives. Pharmazie 1999, 54, 359-361. [CrossRef] [PubMed]

45. Maczyński, M.; Jezierska, A.; Zimecki, M.; Ryng, S. Synthesis, immunological activity and theoretical study of new 5-substituted 3-methylisoxazole[5,4-d] 1,2,3-triazin-4-one derivatives. Acta Pol. Pharm. 2003, 60, 147-150. [PubMed]

46. Jezierska, A.; Maczyński, M.; Koll, A.; Ryng, S. Structure/activity investigations of 5-substituted 3-methylisoxazole[5,4-d]1, 2, 3-triazin-4-one derivatives. Arch. Pharm. 2004, 337, 81-89. [CrossRef] [PubMed]

47. Zimecki, M.; Mączyński, M.; Artym, J.; Ryng, S. Closely related isoxazoles may exhibit opposite immunological activities. Acta Pol. Pharm. 2008, 65, 793-794. [PubMed]

48. Zimecki, M.; Ryng, S.; Maczyński, M.; Chodaczek, G.; Kocieba, M.; Kuryszko, J.; Kaleta, K. Immunosuppressory activity of an isoxazolo[5,4-e]triazepine-compound RM-33 II. Effects on the carrageenan-induced inflammation. Pharmacol. Rep. 2006, 58, 236-241. [PubMed]

49. Kalgutkar, A.S.; Nguyen, H.T.; Vaz, A.D.; Doan, A.; Dalvie, D.K.; McLeod, D.G.; Murray, J.C. In vitro metabolism studies on the isoxazole ring scission in the anti-inflammatory agent lefluonomide to its active alpha-cyanoenol metabolite A771726: Mechanistic similarities with the cytochrome P450-catalyzed dehydration of aldoximes. Drug Metab. Dispos. 2003, 31, 1240-1250. [CrossRef] [PubMed]

50. Hamilton, L.C.; Vojnovic, I.; Warner, T.D. A771726, the active metabolite of leflunomide, directly inhibits the activity of cyclo-oxygenase- 2 in vitro and in vivo in a substrate-sensitive manner. Br. J. Pharmacol. 1999, 127, 1589-1596. [CrossRef] [PubMed]

51. Yao, H.W.; Li, J.; Chen, J.Q.; Xu, S.Y. A 771726, the active metabolite of leflunomide, inhibits TNF-alpha and IL-1 from Kupffer cells. Inflammation 2004, 28, 97-103. [CrossRef] [PubMed]

52. Leng, L.; Chen, L.; Fan, J.; Greven, D.; Arjona, A.; Du, X.; Austin, D.; Kashgarian, M.; Yin, Z.; Huang, X.R.; et al. A small-molecule macrophage migration inhibitory factor antagonist protects against glomerulonephritis in lupus-prone NZB/NZW F1 and MRL/lpr mice. J. Immunol. 2011, 186, 527-538. [CrossRef] [PubMed]

53. Stosic-Grujicic, S.; Cvetkovic, I.; Mangano, K.; Fresta, M.; Maksimovic-Ivanic, D.; Harhaji, L.; Popadic, D.; Momcilovic, M.; Miljkovic, D.; Kim, J.; et al. A potent immunomodulatory compound, $(S, R)$-3-Phenyl-4,5-dihydro-5-isoxazole acetic acid, prevents spontaneous and accelerated forms of autoimmune diabetes in NOD mice and inhibits the immunoinflammatory diabetes induced by multiple low doses of streptozotocin in CBA/H mice. J. Pharmacol. Exp. Ther. 2007, 320, 1038-1049. [PubMed]

54. Ryng, S.; Zimecki, M.; Fedorowicz, A.; Jezierska, A. Reactions of 5-amino-3-methylisoxazole-4-carboxylic acid hydrazide with carbonyl compounds: Immunological activity and QSAR studies of products. Arch. Pharm. 2001, 334, 71-78. [CrossRef]

55. Mitchell, S.; Li, X.; Woods, M.; Garcia, J.; Hebard-Massey, K.; Barron, R.; Samuel, M. Comparative effectiveness of granulocyte colony-stimulating factors to prevent febrile neutropenia and related complications in cancer patients in clinical practice: A systematic review. J. Oncol. Pharm. Pract. 2016, 22, 702-716. [CrossRef] [PubMed] 
56. Renwick, W.; Pettengell, R.; Green, M. Use of filgrastim and pegfilgrastim to support delivery of chemotherapy: Twenty years of clinical experience. BioDrugs 2009, 23, 175-186. [CrossRef] [PubMed]

57. Talmadge, J.E.; Jackson, J.D.; Borgeson, C.D.; Perry, G.A. Differential recovery of polymorphonuclear neutrophils, B- and T-cell sub-populations in the thymus, bone marrow, spleen and blood of mice following split-dose polychemotherapy. Cancer Immunol. Immunother. 1994, 39, 59-67. [CrossRef] [PubMed]

58. Drozd-Szczygieł, E.; Ryng, S.; Zimecki, M. 7-amino-3,5-dimethylisoxazole [5,4-e] [1,3,4]-triazepin-4-one- a potential new lead structure: Its structure, physicochemical properties and biological activity. Acta Pol. Pharm. 2004, 61, 84-85. [CrossRef] [PubMed]

59. Zimecki, M.; Stepniak, D.; Szynol, A.; Kruzel, M.L. Lactoferrin regulates proliferative response of human peripheral blood mononuclear cells to phytohemagglutinin and mixed lymphocyte reaction. Arch. Immunol. Ther. Exp. 2001, 49, 147-154.

Sample Availability: Sample Availability: Not available.

(C) 2018 by the authors. Licensee MDPI, Basel, Switzerland. This article is an open access article distributed under the terms and conditions of the Creative Commons Attribution (CC BY) license (http://creativecommons.org/licenses/by/4.0/). 